\title{
UTILITY OF PCR ASSAY FOR DETECTION OF BOVINE VIRAL DIARRHEA VIRUS IN CLINICAL SAMPLES FROM PERSISTENTLY INFECTED CATTLE
}

\author{
G. S. Radwan \\ Genetic Engineering and Biotechnology Research Institute, \\ Minufiya University, Sadat City, Egypt.
}

\begin{abstract}
In this study, a polymerase chain reaction (PCR) assay was used for the detection of bovine viral diarrhea virus (BVDV) persistent infections in cattle. BVDV RNA's from individual serum, milk and semen clinical specimens from persistently infected (PI) cattle were transcribed to cDNA using reverse transcriptase. Using a set of oligonucleotide primers complementary to nucleotide sequence within the conserved 5' untranslated region (UTR) of the BVDV genome, a 246 base pair target sequence from BVDV cDNA from clinical samples was successfully amplified by PCR. The sensitivity of PCR detection of BVDV nucleic acid was 10 times more than that of $B V D V$ isolation from serum of PI animals. The results suggest that PCR amplification assay may be a useful addition in developing new rapid and sensitive tests for detection of BVDV in clinical samples from PI animals. The speed and the sensitivity of this method might be of value for perusing studies on pathogenesis and epidemiology of persistent infection of cattle with BVD virus.
\end{abstract}

\section{INTRODUCTION}

Bovine viral diarrhea virus (BVDV) is a pestivirus of worldwide occurrence that cause severe economic losses due to decreased fertility, abortion, diarrhea, respiratory disease and development of a state of 
persistent infection in cattle (Meyling et al., 1990; Hessman et al., 2009). Infection with BVDV can result in at least three possible disease syndromes: bovine viral diarrhea, mucosal disease, and fetal disease (Brownlie, 1985).

Transmission may be vertical or horizontal, and may result in acute or persistent infection (Baker, 1987; Fulton et al., 2005a). Infection In utero may result in abortion, teratogenesis, stillbirths, or the birth of PI, immunotolerant animals (McClurkin et al., 1984).

Persistent infection is usually established by noncytopathic (NCP) biotypes of BVDV by infection of fetuses in utero before 110 to 120 days of gestation (Brownlie et al., 1984; Bolin et al., 1985 b). Mutation of NCP to a cytopathic (CP) biotype, or super infection with an antigenically related CP biotype in PI animals, leads to the development of the usually fatal mucosal disease (Brownlie et al., 1984; Bolin et al., $1985 \mathrm{~b}$ and $\boldsymbol{c}$ ). PI animals generally remain life-long virus carriers, shedding large quantities of virus in most bodily excretions and secretions (Duffell and Harkness, 1985; Roeder and Harkness, 1986; Marley et al., 2009). They are a significant source of infection to other cattle, thus perpetuating BVDV in the herd (Bolin et al., $1985 \mathrm{a}$; Werdin et al., 1989; Fulton et al., 2005a). Calves that are offspring of PI animals are also PI and immunotolerant to strains of BVDV that are antigenically similar to the persistently infecting strain (Baker, 1987).

Horizontally transmitted virus may result in diarrhea in young calves and the virus has been suggested to be immunosuppressive, having an auxiliary role in the establishment of opportunistic infections by other pathogens (Potgieter et al., 1984). 
BVDV is also a frequent contaminant in fetal bovine serum and other bovine products used in cell culture systems (Rossi et al., 1980). This infection presents a great problem for research laboratories and biological industries (Bolin et al., 1991).

Measures for prevention and control of BVDV infections center on the detection and removal of animals PI with BVDV and the prevention of transplacental infections (Duffell and Harkness, 1985; Harkness, 1987; Bolin, 1990b; Letellier et al., 2005). The techniques currently in use for isolation or detection of BVDV in contaminated cell cultures as well as in clinical samples from PI animals are virus isolation in cell culture followed by immunofluorescence or immunoperoxidase staining assays Cornish et al., 2005; Edmondson et al., 2007). These techniques are time-consuming and are too insensitive for detecting very low levels of infectious virus (Sandvick, 1999). Sensitive and novel approaches are needed to trace the spread and circulation of BVDV as well as to study the pathogenesis of the disease (Collect et al., 1989). The polymerase chain reaction (PCR), using Taq DNA polymerase of Thermus aquaticus has been shown to be a rapid and sensitive method for in vitro amplification of specific sequences of nucleic acids (Brock, 1995).

PCR amplification assay has been used for detection of animals PI with BVDV (Brock and Radwan, 1993; Deregt et al., 2002; Cornish et al., 2005; Kennedy et al., 2006; Fulton et al., 2006). The aim of this study was to apply PCR assay for the detection of BVDV in individual clinical samples from PI animals using primers that amplify sequences near to the 5' end of the BVDV genome. 


\section{MATERIALS AND METHODS}

\section{Animals and sampling:}

Serum and milk samples were collected from 140 heifers and adult lactating cows maintained on herds with histories of abortion, weak calves and respiratory disease, suggestive of BVDV infection. In addition, semen samples were also collected from a bull previously identified as PI with BVDV. Serum, milk and semen samples from BVDV-free animals were also tested as negative controls. Processed clinical samples were examined by virus isolation. Persistent BVDV infection was verified by giving dual positive results of serum by virus isolation on 2 successive testing ( 3 weeks apart). PCR assay was applied on serum and milk samples from heifers and adult lactating cows, found positive on BVD virus isolation, and semen samples from PI bulls were further tested by PCR amplification assay.

\section{Conventional diagnostic procedures:}

Bovine turbinate (BT) cells were used for BVDV isolation and quantification according to the procedures described by Brock (1991). BT cell monolayers were inoculated with 1-ml volume of clinical samples. NCP BVD virus isolation from the specimens was attempted after 2 consecutive passages, 4 days each. The CP BVDV NADL strain (National Animal Disease Center, USDA, Ames, IA, USA) and the NCP BVDV SD-1 strain (Dr. K.V. Brock, College of Veterinary Medicine, Auburn University, Auburn, Alabama, USA) were tested as reference. For BVDV quantification in serum samples, 50 $\mu$ l volumes of each 10fold sample dilutions in DMEM were inoculated onto BT cell monolayers in 96-well plates in replicates of 3. The results were assessed by indirect immunoperoxidase method (Afshar et al., 1989). 


\section{RNA extraction:}

Total RNA was isolated from $1 \mathrm{ml}$ samples of BVDV infected cell culture suspensions or individual clinical samples using the lysis and RNA extraction procedures described by Chomczynski and Sacchi (1987). RNA concentration was measured by spectrophotometry at 280 nm.

\section{Reverse transcription (RT) and PCR:}

In order to perform the RT reaction, the following reagents were added to $8.5 \mu$ l extracted RNA: $4 \mu \mathrm{l} 5 \mathrm{X}$ RT buffer $(250 \mathrm{mM}$ Tris-HCl [pH8.3], $375 \mathrm{mM} \mathrm{KCl}, 15 \mathrm{mM} \mathrm{MgCl}_{2}$ ), $2 \mu$ dithiothreitol (100 mM stocks), $2 \mu \mathrm{l}$ deoxynucleotide triphosphates (10 $\mathrm{mM}$ stocks), $0.5 \mu \mathrm{l}$ RNasin (40 units/ $\mu$ l stocks), $2 \mu$ random hexamer primer $(3 \mathrm{pg} / \mu \mathrm{l}$ stocks), $1 \mu \mathrm{l}$ M-MLV reverse transcriptase (200 units/ $\mu$ l stocks). The reaction mixtures were incubated at $37^{\circ} \mathrm{C}$ for 1 hour, subsequently heat inactivated at $75^{\circ} \mathrm{C}$ for 10 minutes. The cDNA product was chilled on ice for immediate PCR testing or stored at $-20^{\circ} \mathrm{C}$.

The 18-bp primers 5'UTR 1 (5' GGC TAG CCA TGC CCT TAG 3') and 5'UTR 2 (5' GCC TCT GCA GCA CCC TAT 3') were synthesized (Research Genetics used for amplification of BVDV cDNA. The oligonucleotide primers were designed based on the published NADL (Collect et al., 1988), Osloss (Renard et al., 1987) and SD-1 (Deng and Brock, 1992) BVDV nucleotide sequence data. Target sequence is located between the bases 100 and 345 within the 5' UTR of BVDV genome.

Amplification of BVDV cDNA was performed as previously described (Radwan et al., 1995). Briefly, PCR buffer (50 mM KCl, 10 $\mathrm{mM}$ Tris-HCl [pH8.3]), $125 \mathrm{pmol}$ 5' UTR 1 and 5' UTR 2 primers, and 2.5units AmpliTaq DNA polymerase $1.5 \mathrm{mM} \mathrm{MgCl}_{2}$ and nuclease-free 
water were added to the $20 \mu \mathrm{l}$ cDNA template in a total volume of $100 \mu 1$. The PCR mixture was initially denatured at $94^{\circ} \mathrm{C}$ for 4 minutes. PCR was allowed to run for 30 cycles in a DNA thermal cycler. Each cycle included three steps; template denaturation for 1 minute at $94^{\circ} \mathrm{C}$, primer annealing for 1.5 minutes at $55^{\circ} \mathrm{C}$ and primer extension for 3 minutes at $72^{\circ} \mathrm{C}$. The reaction mixture was further incubated at $72^{\circ} \mathrm{C}$ for 7 minutes as a final extension step. In each amplification round, a negative control reaction mixture of all reagents with no template added was used.

\section{Agarose gel electrophoresis of PCR products:}

To visualize the yield, $10 \mu \mathrm{l}$ of PCR products were subjected to electrophoresis at $100 \mathrm{~V}$ for 45 min on $1 \%$ agarose gels in $1 \mathrm{X}$ TAE buffer. The gels were stained with $0.5 \mu \mathrm{g} / \mathrm{ml}$ of ethidium bromide as described by Sambrook et al. (1989). The $1 \mathrm{~Kb}$ ladder was used as a molecular weight marker to determine the length of the amplified fragment. The gels were examined under UV light and photographed. Amplification of a 246-bp fragment indicated a positive PCR result.

\section{Sensitivity of BVDV detection by PCR in serum samples:}

A dilution experiment using serum samples from PI animal (adult lactating cow) was done in order to determine the sensitivity of PCR amplification for detection of BVDV. Serum samples (contained $\left.10^{5} \mathrm{CCID}_{50} / \mathrm{ml}\right)$ were serially diluted $\left(10^{-1}\right.$ to $\left.10^{-5}\right)$ with serum from a BVDV-free cow in duplicate. One series was processed for RNA extraction, reverse transcription and PCR amplification as described above. The other series was processed for virus isolation for two passages followed by BVDV antigen detection by immunoperoxidase as described above. 


\section{RESULTS}

Four $(2.8 \%)$ out of 140 heifers and adult lactating cows were identified as PI with BVDV by virus isolation on cell culture ; 2 were heifers (PI animals \#1 and 2) and 2 adult lactating cows (PI animals \#3 and 4 ). Parallel testing of clinical samples from BVDV PI animals were done by virus isolation and by the PCR analysis. BVD virus was detected in all various samples collected from PI animals (serum, milk and semen). The titers in serum from PI animals \#1-4 ranged from $10^{4.3}$ to $10^{5.0} \mathrm{CCID}_{50}$ of BVDV/ml (Table 1). Milk samples from PI animals \#3 and 4 were with titers of $10^{6.5}$ and $10^{5.5} \mathrm{CCID}_{50}$ of $\mathrm{BVDV} / \mathrm{ml}$, respectively. The titer in semen from PI bull was \#5 was $10^{4.0} \mathrm{CCID}_{50}$ of $\mathrm{BVDV} / \mathrm{ml}$.

In this study, PCR oligonucleotide primers were synthesized to the highly conserved 5' UTR of BVDV genome to amplify specific sequences from BVDV. The primer pair of 5' UTR 1 and 5' UTR 2 produced a fragment of $246 \mathrm{bp}$ after amplification.

RNA extracted from BT cells infected with the reference CP BVDV NADL and NCP BVDV SD-1 strains were tested with primer set in the PCR procedure. Figure 1 shows the results of PCR amplification of BVDV cDNA from infected BT cell cultures. DNA fragment of 246 bp was resolved after agarose gel electrophoresis from cell cultures infected with NADL and SD-1 strains (lanes 3 and 4, respectively). Uninfected BT cells from which RNA was extracted tested negative for BVDV (lane 5). Moreover, PCR negative control sample with no cDNA template failed to produce amplification (lane 2). 
Results of PCR amplification of BVDV sequences from serum, milk and semen clinical samples from BVDV PI animals are given in Figure 2. BVDV RNA was detected by PCR analysis in serum samples from PI heifers and adult lactating cows (panel A; lanes 3-6). The difference in the intensity of PCR product DNA's from PI animals \#1- 4 appears to reflect the differences in the titers of BVDV in the serum of these viremic animals. PCR amplification identified BVDV RNA extracted from milk samples collected from PI adult lactating cows (panel B; lanes 3 and 4). Amplified PCR product was also obtained from semen sample of the PI bull (panel C; lane 3). No amplification product DNA was observed with serum, milk and semen samples from BVDVfree animals used as negative controls (lanes 7, 5 and 4, in panels A, b and $\mathrm{C}$, respectively).

A dilution experiment was done in order to determine the sensitivity of BVDV RNA detection using PCR analysis with that of infectious virus isolation assay. In this experiment serum from PI animal \#4 (adult lactating cow) was 10-fold serially diluted in duplicate with serum from a BVDV-free cow. One series was processed for RNA isolation and PCR analysis and the other series was used for infectious virus isolation assay. Up to a dilution of $10^{-3}$ (corresponds to $10^{2}$ $\left.\mathrm{CCID}_{50} / \mathrm{ml}\right), \mathrm{BVDV}$ was still detected by both methods. However, only PCR analysis revealed the presence of BVDV RNA at a dilution of $10^{-4}$ (corresponds to $10 \mathrm{CCID}_{50} / \mathrm{ml}$ ) (Fig.3 and table 2). In this case, PCR analysis was 10 times more sensitive than virus isolation in detecting BVDV. 
Utility Of Pcr Assay For Detection Of Bovine Viral Diarrhea Virus ...

Table (1): BVDV titers in clinical samples from PI animals.

\begin{tabular}{||l|c|c|c||}
\hline \multicolumn{1}{|c||}{ Animal } & \multicolumn{3}{|c|}{ Clinical sample } \\
\cline { 2 - 4 } & $\begin{array}{c}\text { CCID 50/ ml } \\
\text { Serum }\end{array}$ & CCID 50/ ml Milk & $\begin{array}{c}\text { CCID 50/ ml } \\
\text { Semen }\end{array}$ \\
\hline \hline BVDV PI \#1(heifer) & $10^{4.3}$ & N.D & N.D \\
BVDV PI \#2 (heifer) & $10^{4.4}$ & N.D & N.D \\
BVDV PI \#3 (adult lactating cow) & $10^{4.5}$ & $10^{6.5}$ & .D.D \\
BVDV PI \#4 (adult lactating cow) & $10^{5.0}$ & $10^{5.5}$ & N.D \\
BVDV PI \#5 (bull) & N.D & N.D & $10^{4.0}$ \\
\hline
\end{tabular}

$\mathrm{N} . \mathrm{D}=$ not done

Table (2): Sensitivity of PCR and infectious virus assay in the detection of BVDV in serum samples ${ }^{\mathrm{a}}$.

\begin{tabular}{|l||c|c||c||c||c|}
\hline \multicolumn{1}{|c||}{ Test } & \multicolumn{5}{c|}{ Dilution $^{\mathbf{b}}$} \\
\cline { 2 - 6 } & $\mathbf{1 0}^{-1}$ & $\mathbf{1 0}^{-2}$ & $\mathbf{1 0}^{-\mathbf{3}}$ & $\mathbf{1 0}^{-4}$ & $\mathbf{1 0}^{-5}$ \\
\hline \hline Virus assay & + & + & + & - & - \\
PCR $^{\mathrm{c}}$ & + & + & + & + & - \\
\hline \hline
\end{tabular}

${ }^{\mathrm{a}}$ From PI animal \# 3 (adult lactating cow).

${ }^{\mathrm{b}}$ Undiluted serum contained $10{ }^{5.0} \mathrm{CCID}_{50} \mathrm{BVDV} / \mathrm{ml}$.

${ }^{\mathrm{c}}$ The presence or absence of the BVDV specific amplification product is indicated with "+" or "-" respectively.

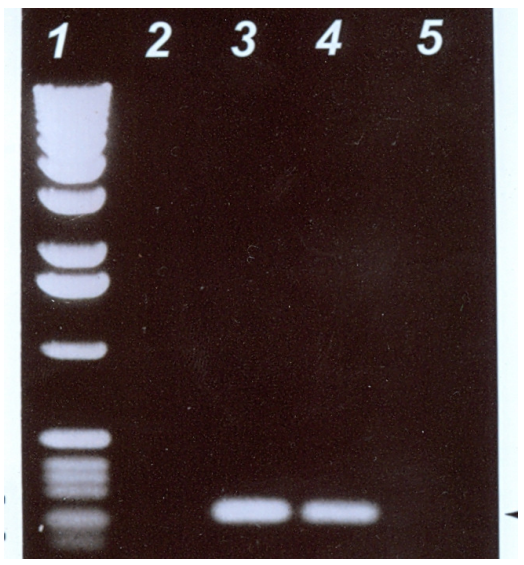

Fig. (1): Electrophoresis on 1\% agarose gel of PCR amplified fragment from cell cultures infected with BVDV strains using 5' UTR 1 and 5' UTR 2 primers. Lane 1: $1 \mathrm{~Kb}$ ladder; lane 2: PCR negative control mix with no cDNA template; lane 3: BVDV strain NADL; lane 4: BVDV strain SD-1; lane 5: uninfected BT cells. Molecular weights of some marker fragments of $1 \mathrm{~Kb}$ ladder are indicated on the left. An arrow on the right indicates the 246-bp amplified product. 


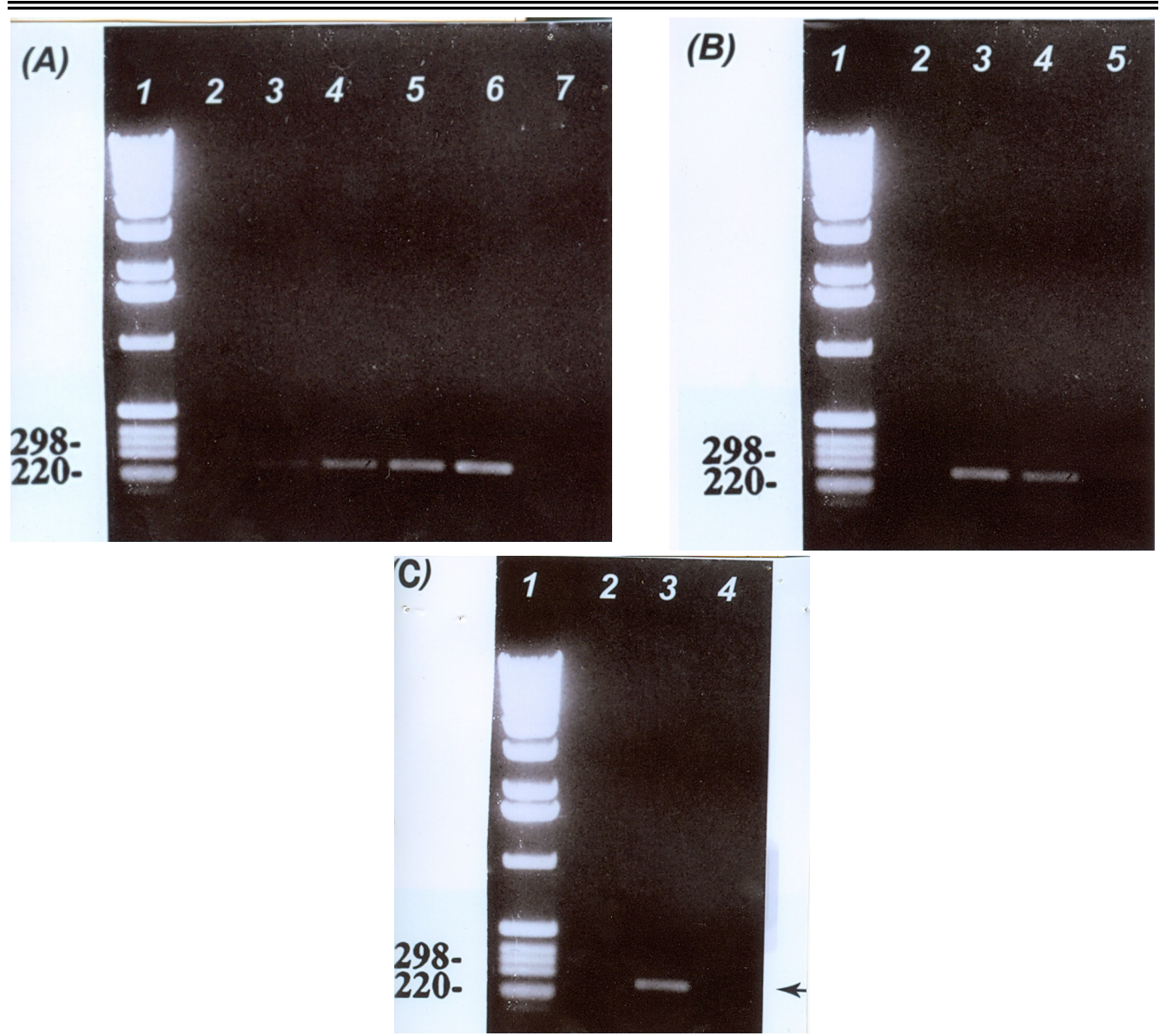

Fig. (2): Agarose gel electrophoresis of PCR amplification products of BVDV cDNA from serum (A), milk (B) and semen (C) samples of PI animals. A) Lanes: 3-6, serum samples from heifers (PI animals \#1 and \#2) and adult lactating cows (PI animals \#3 and \#4), respectively. B) Lanes: 3 and 4: milk samples from adult lactating cows (PI animals \#3 and \#4), respectively. C) Lane 3: semen sample from the bull (PI animal \#5). Lanes 7, 5 and 4 in panels (A), (B) and (C): serum, milk and semen samples from BVDV-free animals, respectively (negative controls). Lanes 2 in each panel: PCR negative control mix with no cDNA template. Molecular weights of some marker fragments of $1 \mathrm{~kb}$ ladder (lane 1 in each panel) are indicated on the left of each panel. An arrow on the right of each panel indicates the 246-bp amplified product. 


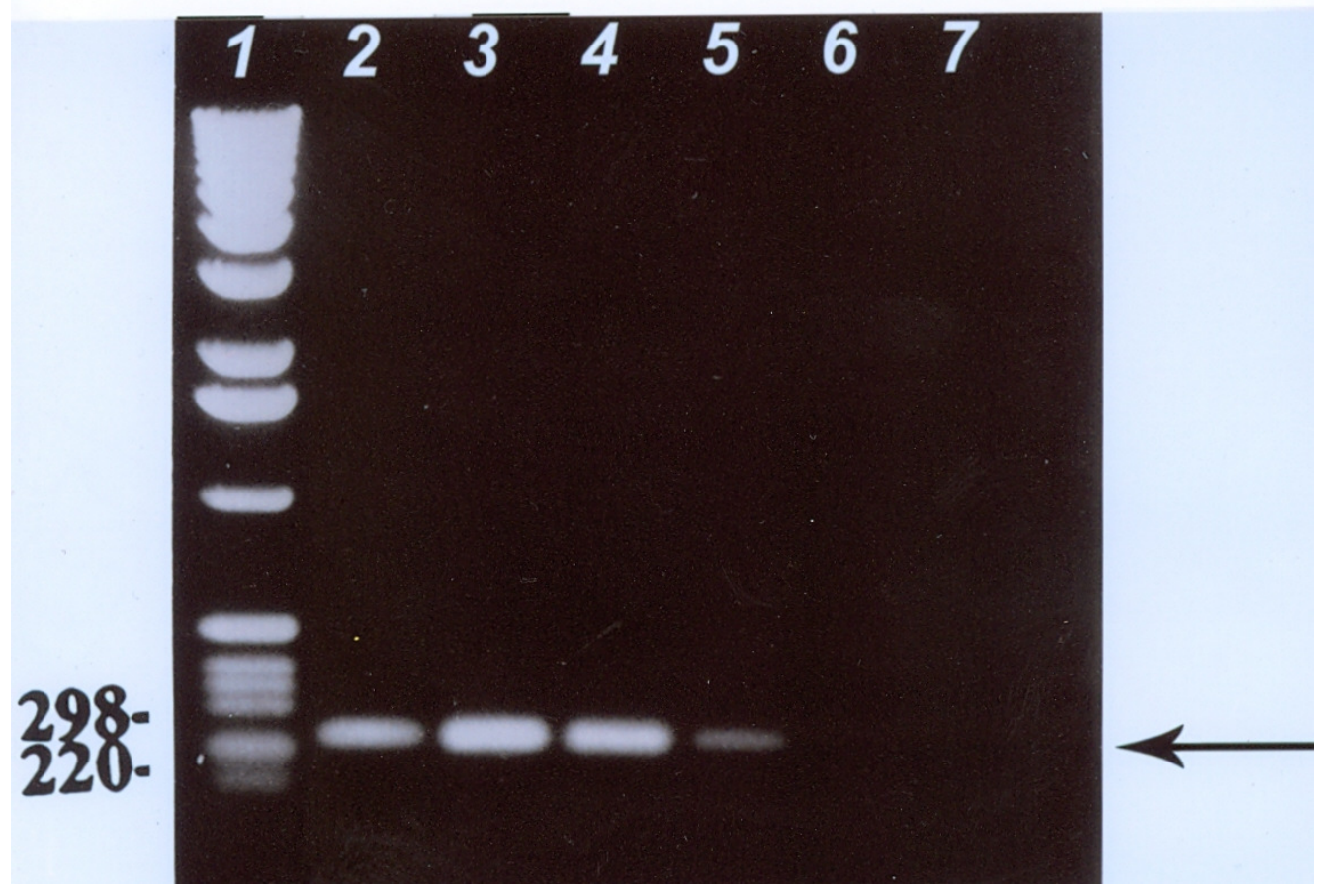

Fig. (3): Sensitivity of PCR detection of BVDV in serum of PI animals in the diagnosis of BVDV. Serum from PI \#4 $\left(10^{5} \mathrm{CCID}_{50} / \mathrm{ml}\right)$ was 10 -fold serially diluted in serum from a BVDV-free cow. RNA was isolated from $1 \mathrm{ml}$ of each dilution, reverse transcribed and amplified. PCR products were size fractionated on agarose gel. Serum dilutions were from $10^{-1}$ to $10^{-5}$ in lanes $2-6$, respectively; lane 7: PCR negative control mix with no cDNA template. Molecular weights of some marker fragments of $1 \mathrm{~Kb}$ ladder (lane 1) are indicated on the left. An arrow on the right indicates the 246-bp amplified product. 


\section{DISCUSSION}

BVDV is a ubiquitous pathogen of cattle with worldwide economic importance (Bolin, 1990a). A significant epizootiologic trait of BVDV is the development of PI animals. Identification of PI animals, in combination with a proper vaccination programs, is essential for the successful control of BVDV (Harkness, 1987; Bolin, 1990b; Fulton et al., 2005a). Standard BVDV detection protocols, which use a combination of cell culture and various immunoassays. Cell culture assays are labor-intensive and lengthy, usually requiring several days for completion (Hamel et al., 1995). On the other hand, Detection of BVDV by antibody-based techniques is also difficult because of BVDV antigenic variation (Xue et al., 1990). The aim of this study was to apply PCR assay for the detection of BVDV RNA in cell culture and in individual clinical samples and specimens from PI animals. By this approach, BVDV persistent infection can be rapidly and specifically diagnosed.

In this study BVDV persistent infection was identified by virus isolation in $4(2.85 \%)$ out of 140 heifers and adult lactating cows. These results are in agreement with the prevalence of persistent BVDV infection ranging from 0.5 to $3 \%$ reported by Muñoz-Zanzi et al. (2000).

RNA was extracted from infected cell cultures and individual clinical samples using the potent protein denaturant guanidinium isothiocynate, which has been used to isolate intact biologically active RNA from RNase-rich tissues (Chomczynski and Sacchi, 1987). The use of this ingredient and protocol was efficient, fast, reliable and reproducible. Because BVDV is an RNA virus, it was necessary first reverse transcribe the viral RNA into single stranded cDNA, which was then used for the enzymatic amplification (Brock, 1991; Hamel et al., 1995). 
The oligonucleotide primer set used in this study was selected from regions of high nucleotide and amino acid conservation within the 5' UTR of BVDV genome (Letellier et al., 1999). This study revealed that BVDV RNA could be detected in infected cells by reverse transcription followed by PCR amplification. Virus-specific amplification products of the expected sizes were found with both $\mathrm{CP}$ BVDV reference strain NADL and NCP BVDV strain SD-1 tested. No amplification was obtained with total RNA from uninfected cells used as negative control. The problem of BVDV contamination of cell lines, particularly with NCP strains, can be easily investigated using the technique described. It should be possible to screen batches of bovine sera for BVDV by PCR (Rossi et al, 1980; Bolin et al., 1991; Zabal et., 2000).

Specific amplification products were consistently obtained from individual clinical samples and specimens from PI animals sampled in this study.

Because PCR permits the amplification of few BVDV particles, caution was exercised to avoid any possibility of generating false-positive results due to carry-over contamination with viral RNA or cDNA in any buffer or reagents (Persing, 1991). Proper negative controls were included in all PCR experiments.

There are several advantages of using PCR amplification to detect BVDV. The most important is the speed and sensitivity of the assay. Due to the sensitivity available using PCR, amplification can be done directly on samples obtained from infected animals (Brock and Radwan, 1993; Schmitt et al., 1994; Hamel et al., 1995; Kennedy et al., 2006). Compared to viral isolation, PCR is much faster, especially with the NCP biotype, which takes longer time to propagate and is the prevalent form 
in nature (Brock, 1995). The time required to obtain PCR results from the time of sample collection could be reduced to 24 hours. This significantly less time than minimal time required to obtain results by using standard viral isolation procedures. Amplification of BVDV cDNA directly from samples collected from infected animals provides the ability to characterize virus without the requirement of virus isolation in cell culture (Fulton et al., 2005b). Not surprisingly, the sensitivity of PCR virus detection method exceeded 10-fold that of virus isolation in cell culture. Similar results regarding the sensitivity of PCR for BVDV detection in clinical samples were reported (Hooft van Iddekinge et al., 1992; Weinstock et al. 2001).

In conclusion, RT-PCR could become useful for rapid detection of BVDV infections in cell culture and clinical materials from individual animals. Due to its exquisite sensitivity, RT-PCR assay could provide a powerful tool in studies on the epidemiology and pathogenesis of animal infections with BVD virus.

\section{REFERENCES}

- Afshar, A., Dulac, G.C. and Bouffard, A. (1989). Application of peroxidase labeled antibody assay for detection of porcine IgG antibodies to hog cholera and bovine viral diarrhea virus. J Virol Methods, 23: 253-262.

- Baker, J.C. (1987). Bovine viral diarrhea virus: a review. J Am Vet Assoc, 190:1449-1458.

- Bolin, S.R. (1990a). The current understanding about the pathogenesis and clinical forms of BVD. Vet Med, 85:1123-1132.

- Bolin, S.R. (1990b). Control of bovine viral diarrhea virus. Rev Sci Tech Off Int Epizoot, 9: 163-171. 
- Bolin, S.R., Matthews, P.J. and Ridpath, J.F. (1991). Methods for detection and frequency of contamination of fetal calf serum with bovine viral diarrhea virus and antibodies against bovine viral diarrhea virus. J Vet Diagn Invest, 3:199-203.

- Bolin, S.R., McClurkin, A.W. and Coria, M.F. (1985 a). Frequency of persistent bovine viral diarrhea virus infection in selected cattle herds. Am J Vet Res, 46: 2385-2387.

- Bolin, S.R., McClurkin, A.W., Cutlip, R.C. and Coria, M.F. (1985 b). Severe clinical disease induced in cattle persistently infected with noncytopathic bovine viral diarrhea virus by super-infection with cytopathic bovine viral diarrhea virus. Am J Vet Res, 46: 573-576.

- Bolin, S.R., McClurkin, A.W., Cutlip, R.C. and Coria, M.F. (1985 c). Response of cattle persistently infected with noncytopathic bovine viral diarrhea virus to vaccination for bovine viral diarrhea and to subsequent challenge exposure with cytopathic bovine viral diarrhea virus. Am J Vet Res, 46: 2467- 2470.

- Brock, K.V. (1991). Detection of persistent bovine diarrhea virus infections by DNA hybridization and polymerase chain reaction. ArchVirol, [Suppl.3]: 199-208.

- Brock, K.V. (1995). Diagnosis of bovine viral diarrhea virus infections. Vet Clin North Am Food Anim Pract, 11:549-561.

- Brock, K.V. and Radwan, G.S. (1993). Detection of bovine viral diarrhea virus in bulk milk samples by PCR amplification. In proceeding of the 2nd Symposium on pestiviruses, October 1-3, 1992. (edited by S. Edwards), Lyon France; Foundation Marcel Merieux: 223- 226. 
- Brownlie, J. (1985). Clinical aspects of bovine virus diarrhoea/ mucosal disease complex in cattle. In Practice, 7: 195-200.

- Brownlie, J., Dark, M.C. and Howard, C.J. (1984). Experimental production of fatal mucosal disease in cattle. Vet Rec, 114: 535-536.

- Chomczynski, P. and Sacchi, N. (1987). Single step method of RNA isolation by acid guanidium thiocynate-phenol-chloroform extraction. Anal Biochem, 162: 156-159.

- Collect, M.S., Larson, R., Gold, C., Strick, D., Anderson, D.K. and Purchio, A.F. (1988). Molecular cloning and nucleotide sequence of the pestivirus bovine viral diarrhea virus. Virology, 165: 191-199.

- Collect, M.S., Moening, V. and Horzinek, M.C. (1989). Recent advances in pestivirus research: Review article. J Gen Virol, 70: 253266.

- Cornish, T.E., van Olphen, A.L., Cavender, J.L., Edwards, J.M., Jaeger, P.T., Vieyra, L.L., Woodard, L.F., Miller, D.R. and O'Toole, D. (2005). Comparison of ear notch immunohistochemistry, ear notch antigen-capture ELISA, and buffy coat virus isolation for detection of cavles persistently infected with bovine viral diarrhea virus. J Vet Diagn Invest, 17:110-117.

- Deng, R. and Brock, K.V. (1992): Molecular cloning and nucleotide sequence of a pestivirus genome, noncytopathic bovine viral diarrhea virus strain SD-1. Virology, 191: 867-879.

- Deregt D., Carman, P.S., Clark, R.M., Burton, K.M., Olson, W.O. and Gilbert, S.A. (2002). A comparison of polymerase chain reaction with and without RNA extraction and virus isolation for detection of bovine viral diarrhea virus in young calves. J Vet Diagn Invest, 14(5):433-437. 
- Duffell, S.J. and Harkness, J.W. (1985). Bovine viral diarrheamucosal disease infection in cattle. Vet Rec, 117: 240-245.

- Edmondson, M.A., Givens, M.D., Walz, P.H., Gard, J.A., Stringfellow, D.A. and Carson, R.L. (2007). Comparison of tests for detection of bovine viral diarrhea virus in diagnostic samples. J Vet Diagn Invest, 19: 376-381.

- Fulton, R.W., Briggs, R.E., Ridpath, J.F., Saliki, J.T., Confer, A.W., Payto, N., M.E., Duff, G.C., Step, D.L. and Walker, D.A. (2005a). Transmission of bovine viral diarrhea virus $1 \mathrm{~b}$ to susceptible and vaccinated calves by exposure to persistently infected calves. Can J Vet Res, 69:161-169.

- Fulton, R.W., Ridpath, J.F., Ore, S., Confer, A.W., Saliki, J.T., Burge, L.J. and Payton, M.E. (2005b). Bovine viral diarrhoea virus (BVDV) subgenotypes in diagnostic laboratory accessoions: distribution of BVDV1a, 1b, and 2a subgenotypes. Vet Microbiol, 111: 35-40.

- Fulton, R.W., Hessman, B., Johnson, B.J., Ridpath, J.F., Saliki, J.T., Burge, J.L., Sjeklocha, D., Confer, A.W., Funk, R.A. and Payton, M.E. (2006). Evaluation of diagnostic tests used for detection of bovine viral diarrhea virus and prevalence of subtypes 1a, 1b, and $2 \mathrm{a}$ in persistently infected cattle entering a feedlot. J Am Vet Med Assoc, 228: 578-584.

- Hamel, A.L., Wasylyshen, M.D. and Nayar, G.P. (1995). Rapid detection of bovine viral diarrhea virus by using RNA extracted directly from assorted specimens and a one-tube reverse transcription PCR assay. J Clinic Microbiol, 33: 287-291. 
- Harkness, J.W. (1987): The control of bovine viral diarrhea virus infection. Ann Rech Vet, 18: 167-174.

- Hessman, B.E., Fulton, R.W., Sjeklocha, D.B., Murphy, T.A., Ridpath, J.F. and Payton, M.E. (2009). Evaluation of economic effects and the health and performance of the general cattle population after exposure to cattle persistently infected with bovine viral diarrhea virus in a starter feedlot. Am J Vet Res, 70: 73-85.

- Kennedy, J.A., Mortimer, R.G. and Powers, B. (2006). Reverse transcription-polymerase chain reaction on pooled samples to detect bovine viral diarrhea virus by using fresh ear-notch-sample supernatants. J Vet Diagn Invest, 18:89-93.

- Hooft van Iddekinge, B.J.L.H., van Wamel, J.L.B., van Gennip, H.G.P. and Moormann, R.J.M. (1992). Application of the polymerase chain reaction to the detection of bovine viral diarrhea virus infections in cattle. Vet Microbial, 30: 21-34.

- Letellier, C., De Meulemeester, L., Lomba, M., Mijten, E. and Kerkhofs, $\boldsymbol{P}$. (2005). Detection of BVDV persistently infected animals in Belgium: evaluation of the strategy implemented. Prev Vet Med, 72:121-125; discussion 215-219.

- Letellier, C., Kerkhofs, G., Wellemans, G. and Vanodenbosch, E. (1999). Detection and genotyping of bovine viral diarrhea virus by reverse transcription-polymerase chain reaction. Vet Microbiol, 64: 155-167.

- Marley, M.S., Tabor, J.M., Givens, M.D., Kaproth, M., Riddell, K.P., Galik, P.K., Zhang, Y. and Eason, A.B. (2009). Bovine viral diarrhea virus is inactivated when whole milk from persistently infected cows is heated to prepare semen extender. Vet Microbiol, 134(3-4):249253. 
- McClurkin, A.W., Littledike, E.T., Cutlip, R.C., Frank, G.H., Coria, M.F. and Bolin, S.R. (1984). Production of cattle immunotolerant to bovine viral diarrhea virus. Can J Comp Med, 48: 156-161.

- Meyling, A., Houe, H. and Jensen, A.M. (1990). Epidemiology of bovine viral diarrhea virus. Rev Sci Tech Off Int Epizoot, 9: 75-93.

- Muñoz-Zanzi, C.A., Johnson, W.O, Thurmond, M.C and Hietala, S.K. (2000). Pooled-sample testing as a herd-screening tool for detection of bovine viral diarrhea virus persistently infected cattle. $\mathbf{J}$ Vet Diagn Invest, 12:195-203.

- Persing, D.H. (1991). Polymerase chain reaction: trenches to benches. J. Clin Microbiol, 29:1281-1285.

- Potgieter, L.N.D., McCraken, M.D., Hopkins, F.M., Walker, R.D., and Guy. J.S. (1984). Experimental production of bovine respiratory tract disease with bovine viral diarrhea virus. Am J Vet Res, 45: 15821585.

- Radwan, G.S., Brock, K.V., Hogan, J.S. and Larry Smith, K. (1995). Development of a PCR amplification assay as a screening test using bulk milk samples for identifying dairy herds infected with bovine viral diarrhea virus. Vet Microbiol, 44: 77-92.

- Renard, A., Dina, D. and Martial, J.A. (1987). Complete nucleotide sequence of bovine viral diarrhea genome and its fragment, useful for making antigenic proteins useful for therapy and diagnosis. European Patent Application, No.0208672.

- Roeder, P.L. and Harkness, J.W. (1986). BVD virus infection: prospects for control. Vet Rec, 118: 143-147.

- Rossi, C.R., Bridgman, C.R. and Kiesel, G.K. (1980). Viral contamination of bovine lung cultures and bovine fetal serum. Am J Vet Res, 41: 1680-1681. 
- Sambrook, J., Fritsch, E.F. and Maniatis, T. (1989): Molecular colning. A Laboratory Manual 2nd Ed., Cold Spring Harbor Lab., N.Y.

- Sandvick, T. (1999). Laboratory diagnostic investigation for bovine viral diarrhoea virus infections in cattle Vet Microbiol, 64: 123-134.

- SambrooksTajima, M., Ohsaki, T., Okazawa, M. and Yasutomi, I. (2008). Availability of oral swab sample for the detection of bovine viral diarrhea virus (BVDV) gene from the cattle persistently infected with BVDV. Jpn J Vet Res, 56:3-8.

- Schmitt, B.J., Lopez, O.J., Ridpath, J.F., Galeota-Wheeler, J. and Osorio, F.A. (1994). Evaluation of PCR for diagnosis of bovine viral diarrhea virus in tissue homogenates. J Vet Diagn Invest, 6: 44-47.

- Weinstock, D., Bhuderi, B. and Castro, A.E. (2001). Single-tube single enzyme reverse transcriptase PCR assay for detection of bovine viral diarrhea virus in pooled bovine serum. J Clin Microbiol, 39: 343346.

- Werdin, R.E., Trevor, A.A., Sagar, M.G. and DeVries, G.P. (1989). Diagnostic investigation of bovine viral diarrhea infection in Minnesota dairy herd. J Vet Diagn Invest, 1:57-61.

- Xue, W., Blecha, F. and Minocha, H.C. (1990). Antigenic variations in bovine viral diarrhea viruses detected by monoclonal antibodies. J. Clin Microbiol, 28: 1688-1693.

- Zabal, O., Kobrak, A.L., Lager, I.A., Schudel, A.A. and Weber, E.L. (2000). [Contamination of bovine fetal serum with bovine viral diarrhea virus]. Rev Argent Microbiol, 32:27-32. 


\title{
استخدام اختبار تفاعل إنزيم البلمرة المتسلسل للكثف عن الحمض النووي لفيروس مرض الإسهال

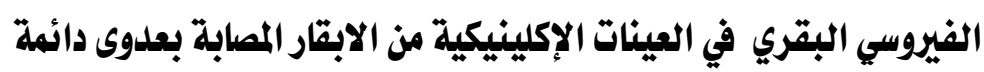

\author{
جمال سليمان رضوان \\ معهد الهنسسة الوراثية و التكنولوجيا الحيوية-جامعة المنوفية- \\ مدينة السادات- المنوفية-جمهورية مصر العربية
}

في هذه الدر اسة تم استخدام اختبار تفاعل إنزيم البلمرة المتسلسل للكثف عن الحمض النووي لفيروس مرض الإسهال الفيروسي البقري في الابقار المصابة بعدوى الفيروس الدائمة. وذلك تم النسخ العكسي للحمض النووي الريبوزي المستخلص من العينات الإكلينيكية (سيرم- لبن- سائل منوي) من حيو انات دائمة الإصابة بالفيروس إلي الحمض النووي الديوكسي ريبوزي المكمل (cDNA) بو اسطة إنزيم النسخ العكسي. و باستخدام زوج من بادئات التفاعل نم اختياره من منطقة قرب نهاية الــ 5' غير المترجمة لبروتين بجينوم الفيروس تم بنجاح مضاعفة منطقة طولها 246 زوجا من القو اعد مستهدفة من الحمض النووي الديوكسي ريبوزي المكمل الخاص بالفيروس في العينات الإكلينيكية من حيو انات دائمة الإصابة بالفيروس بواسطة هذا الاختبار • و لقد كانت حساسية اختبار تفاعل إنزيم البلمرة المتسلسل تفوق مثيلتها بإجر اء طرق عزل الفيروس من مزارع الخلايا بمقدار 10 مر ات للكثف عن الفيروس في عينات سيرم من ابقار دائمة الإصابة بالفيروس. و قد دلت النتائج علي أن تفاعل إنزيم البلمرة المتسلسل يمكن أن يمثل إضافة جديدة في تطبيق اختبار ات سريعة و حساسة للكثف عن الفيروس في العينات الحقلية من الحيو انات المصابة ، كما يمكن الإفادة من سرعة و حساسية هذا الاختبار في در اسات علي وبائية و كيفية حدوث و تطور الإصابة الدائمة بفيروس مرض الإسهال الفيروسي البقري في الماثنية. 